\title{
In die netwerk van nadenke oor die omgewing
}

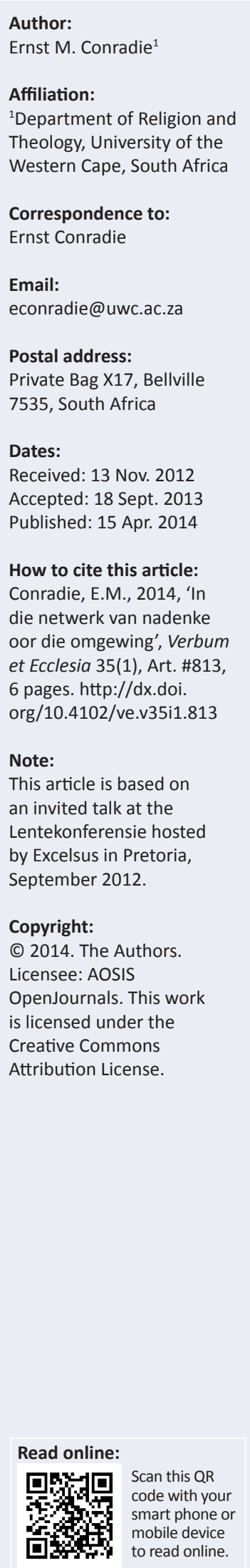

In the network of thinking about the environment. This contribution is based on a talk delivered at a conference for continuous education for pastors. The argument commences with reflections on 'thinking with one's hands', more specifically with engaging in earthkeeping praxis, with getting one's hands dirty. It is suggested that such thinking leads sooner rather than later to a widening network of fundamental questions - about the human condition, the meaning of history, the possibility of knowledge and the social construction of reality itself. A Christian engagement in earthkeeping is therefore not merely a matter of transformative praxis; it also provides churches with an opportunity for fundamental renewal. If so, this may be regarded as an example of thinking globally but acting locally. This underlying logic of inquiry implies that the scope of contemporary ecotheology cannot be restricted to environmental ethics or creation theology. It is this underlying logic of inquiry that this contribution seeks to describe.

\section{Inleiding}

Hierdie bydrae begin met enkele waarnemings oor die moontlikheid daarvan om met 'n mens se hande te kan 'dink', meer spesifiek om jou hande 'vuil' te maak in die vorm van omgewingsorg. My argument is dat sulke denke spoedig wyer uitkring na' $n$ netwerk van veel meer fundamentele vrae - oor menswees, die betekenis van die geskiedenis, die moontlikheid van kennis en die sosiale konstruksie van die werklikheid opsigself. Hoewel hierdie vrae geensins nuut is nie, gaan dit hier oor die wyse waarop sulke vrae oënskynlik spontaan ontlok word. Vanwaar kom dit dat betrokkenheid by omgewingsorg al gou lei na vrae oor menswees, kosmologie en God? In hierdie bydrae word hierdie onderliggende logika van naderby ondersoek en beskryf. Die implikasies hiervan is verreikend: Christelike omgewingsorg kan nie beperk word tot transformatiewe praksis nie. Dit kan nie ingeperk word tot omgewingsetiek of skeppingsteologie nie, maar bied 'n geleentheid vir 'n verreikende ekologiese hervorming van die Christelike tradisie.

\section{Om met jou hande te dink}

Enige iets in 'n mens se omgewing kan jou aan die dink sit. Dit gaan nie hier soseer oor 'n akademiese manier van dink, min of meer op 'n afstand nie, oor nadenke oor iets wat dalk vir jou interessant mag wees nie. Dit gaan ook nie net oor dink op jou voete nie, maar oor dink met jou hele senuweestelsel, meer spesifiek oor dink met jou hande. Ek het op 'n keer 'n lesing bygewoon oor die bou van robotte en die vraag hoe robotte gemaak kan word om uit ervaring te leer. Die deurbraak het glo gekom toe hulle mense se hande en voete gesimuleer het sodat die kleiner rekenaars in die robot se 'hande' terugvoering kon gee aan die sentrale rekenaarstelsel.

Daar is 'n paar mooi voorbeelde van dink met jou hande wat ek in gedagte het:

- In Klip en Klei (1968) praat Marthinus Versfeld oor kos en kook, oor groente- en kruietuine, oor houtwerk en huisbou - en oor spiritualiteit - alles in dieselfde asem.

- In sy Sand County Almanac (1949) skryf Aldo Leopold, die leidende figuur in die 'land ethic' denkrigting oor die waarde daarvan om self die winter se vuurmaakhout van bome op jou eie werf te kap - omdat jy dan leer verstaan wat dit verg en hoe lank dit neem om daardie bome te vervang.

- In Zen and the Art of Motorcycle Maintenance (1974) word Robert Pirsig se nadenke oor die metafisika van kwaliteit as't ware gebore vanuit die ghries aan die hande van sy hoofkarakter.

- My vriend William Everett se roman Red Clay, Blood River (2008) handel oor die historiese verband tussen die trek van die Cherokees en die slag by Bloedrivier, albei in 1838. Die inspirasie vir sy werk het volgens hom alles te make met sy voorliefde vir houtwerk - veral vir die maak van liturgiese meubels.

- Ek kan nie bely dat ek al Angus Buchan se boek Faith like Potatoes (2006) gelees het of beplan om dit ooit te doen nie, maar die titel spreek my nogal aan. Ek dink eerder aan my vrou Marietjie se oom Fritz Breytenbach, 'n innoverende boer met groot sterk hande wat op 'n keer 
vir my gesê het dat hy nie weet wat om te doen as hy in die oggend opstaan nie. Hy het bedoel dat hy na meer as 50 jaar se ervaring van boedery steeds nie weet wat die regte ding is om met sy hande te doen nie, omdat die grond waarmee hy werk só kompleks is dat hy nie mooi weet wat die impak van sy landboumetodes daarop sal wees nie. Hy sien onkruid as 'n simptoom van wat onder die grond gebeur. Hy boer nie met aartappels nie, maar dit gaan vir hom ook oor sy grond-ige (on)kunde.

- Ek vermoed dat daar soortgelyke voorbeelde is van mense wat nadink oor die spiritualiteit van naaldwerk, wynmaak, huisskoonmaak, klavierspeel of wat ook al. Voorbeelde kan sekerlik vermenigvuldig word, maar ek dink nie iemand sal spiritualiteit daarin vind om jou vingers die praatwerk te laat doen deur die geelbladsye nie!

In al hierdie voorbeelde moet jy jou hande vuilmaak om te dink, anders werk dit net nie. In elke geval roep dit vrae op wat jou aan die dink sit. Dit sal interessant wees om te wonder of dieselfde moontlik is vir aktiwiteite soos draf, fietsry, bergklim, perdry, swem of stap. Ek vermoed nie so nie, want dikwels is 'n mense se denke met hierdie soort aktiwiteite te amorf; dit sweef rond sonder om vastrapplek te vind, miskien juis omdat jou voete die dinkwerk doen.

Naas hierdie voorbeelde van dink met jou hande kan 'n mens ook talle voorbeelde van sorg vir die omgewing opnoem. Of liewer: hierdie is nie die enigste voorbeelde van sorg vir die omgewing nie. Vir kerklike betrokkenheid daarby help dit om die volle spektrum van aktiwiteite raak te sien wat as omgewingsorg kan deurgaan. Nie elkeen kan of hoef by alles betrokke te wees nie, maar elkeen kan iets kry wat sy of haar hande vind om te doen (vir 'n meer gedetailleerde bespreking kyk Conradie 2011a). In elke konteks is daar iets anders wat voor die hand liggend is. Ek noem die volgende:

- die maak van kompos

- die herwinning van papier, glas, metaal en plastiek

- die skep van inheemse (kerk)tuine, byvoorbeeld die 'living graveyard campaigns'

- omgewingsoudits van eiendomme in die konteks van 'eko-gemeentes'

- inisiatiewe rondom dierebeskerming

- stedelike landbou, 'edible landscaping', stedelike vergroening

- besparingsmaatreëls veral ten opsigte van water en elektrisiteit

- toepaslike vorms van tegnologie

- plaaslike vorms van aktivisme

- tallose vorme van omgewingsopvoeding

- die aankweek van deugde soos soberheid, dankbaarheid en vergenoegdheid.

Daar kan sekerlik veel meer voorbeelde genoem word en aan die hand van konkrete inisiatiewe geillustreer word. 'n Mens kan sê dat hoe vuiler jou hande word, hoe beter sal jy moet leer dink.

Hierdie maniere van dink met jou hande kan ook as voorbeelde beskou word van wat ek in Waar op dees aarde vind mens God? (Conradie 2006) die soeke na 'n 'aardse spiritualiteit' genoem het. Ek het drie eienskappe van enige vorm van spiritualiteit onderskei, naamlik die klem op ervaring, die aspek van transendensie en die bepaalde vorm waarin hierdie ervaring tot uitdrukking gebring word. In elkeen van die voorbeelde hierbo word só 'n ervaring van transendensie in 'n bepaalde (kuns)vorm tot uitdrukking gebring. Daar kan miskien ook 'n vierde aspek van spiritualiteit onderskei word, naamlik die bepaalde plek waar dit gesitueer word en wat juis hierdie ervaring oproep.

Tradisioneel word 'n eiesoortige Christelike spiritualiteit opgeroep deur spesifieke lokusse waar God se teenwoordigheid ervaar word. Sommige hoor God se stem in die prediking. Ander vind in deelname aan die misterie van die sakramente die sleutel tot God se teenwoordigheid. Nog ander word beweeg deur musiek, deur die meeslurende sing van lofliedere of deur die evangelie uit te speel in die vorm van ritmiese danse. Maar 'n mens kan God se teenwoordigheid ook vind deur meditasie in die stilte van 'n groot katedraal. Of jy kan inspirasie vind in die simboliek van beeldhouwerke, skilderye, ikone, argitektuur of ander kunswerke. Baie vind God in die intimiteit van die gemeenskap van gelowiges in kleiner groepe of in die kontinuiteit van familienetwerke oor geslagte heen. Ander soek 'n meer dramatiese teken van God se teenwoordigheid in die vorm van glossolalie, genesing, die uitdryf van euwels of charismatiese leierskap. Nog ander meen dat hulle God ten beste beleef in die natuur daarbuite. Om te dink met jou hande bied nog 'n paar moontlikhede om God te vind: voor die stoof, by die opwasbak, in die kruietuin, in die houtwerkkamer, in die werkswinkel.

Dit gaan dus hier oor die bepaalde lokus (omgewingsorg) wat ' $n$ mens aan die dink sit, meer nog, wat ervarings van transendensie na vore roep. Dit is trouens heel merkwaardig hoeveel literatuur reeds oor 'n ekologiese spiritualiteit beskikbaar is. Naas Matthew Fox se bekende bydrae oor Creation spirituality (1991) is daar ' $n$ wyd uiteenlopende pluraliteit van benaderings in die verband - vanaf Denis Edwards se herwinning van Basilius se klassieke pneumatologie in Breath of life (2004) tot by talle radikale vorms van inheemse en ekofeministiese spiritualiteit. Die literatuur is eintlik reeds onoorsigtelik en nie maklik in kaart te bring nie - soos wat blyk uit die bydraes oor 'Pneumatologie en Ekologie' wat onlangs in Journal of Reformed Theology (Conradie 2012) verskyn het. Ten spyte van hierdie stortvloed van literatuur is die verband tussen grond en gees vir baie steeds kontra-intuitief. In hierdie bydrae wil ek probeer om die onderliggende logika aan te dui waarvolgens sulke verbande so blitsnel gelê word.

\section{Waaraan dink jy as jy jou hande vuilmaak?}

My opgawe is nie hier om te wys hoe om aktiwiteite rondom omgewingsorg ten beste aan te pak nie. Ander is veel beter daartoe in staat. Ek wil eerder wys op die denkpatrone wat in die proses ontsluit word. Ek wil wys op die warboel van vrae wat vroeër of later opgeroep word deur aktivisme 
rondom omgewingsorg. My argument is eenvoudig: Wanneer jy jou hande op een of ander manier vuilmaak, word jy gekonfronteer met 'n netwerk van vrae waarop jy nie antwoorde het nie, eintlik nie antwoorde kan kry nie, maar nietemin voorlopige antwoorde nodig het om te kan aangaan waarmee jy besig is. Jy word met ander woorde in 'n netwerk van vrae vasgewoel. Omgewingsorg gaan nie net oor sorg vir die omgewing nie; dit verg ' $n$ bepaalde spiritualiteit en roep dit juis na vore. Dit kan ook verduidelik word in terme van die bekende slagspreuk: 'Think globally; act locally'. Konkrete plaaslike handeling roep vrae na vore wat globale denke noodsaaklik maak. Die omgekeerde is natuurlik ook waar, naamlik dat globale denke sonder plaaslike handelinge nutteloos is. Daarom: dit is pas wanneer jy jou hande vuilmaak dat jy leer hoe om globaal te dink. Die klem in hierdie bydrae val wel op hoe globaal daardie denke inderdaad gou-gou word.

Wat ek wil aandui is hoedat hierdie vrae opgeroep word, hoe vanselfsprekendhede daardeur deurbreek word en hoe radikaal daardie vrae is. Dit gaan nie soseer oor watter vrae hier aan die orde is nie en sekerlik nie oor vooraf geopenbaarde Christelike antwoorde op daardie vrae nie. Die vrae is groot vrae, klassieke vrae, filosofiese vrae. Ek wil meer spesifiek die lokus probeer bepaal waar en wanneer hierdie soort vrae opnuut opgeroep word deur nadenke oor omgewingsorg. Ek doen dit wel aan die hand van vier sulke groot vrae, oor die mens, die geskiedenis, kennis en die werklikheid self. Groter as dit kom dit nie eintlik nie.

\section{Hoe verskil die mens van ander spesies?}

Al die klassieke vrae oor menswees word met 'n nuwe dringendheid opgeroep deur omgewingsorg: Wat is 'n mens? Hoe verskil ons van ander spesies? Wat is die implikasies daarvan dat ons ongeveer $99 \%$ van ons gene met sjimpansees deel? Watter verskil maak daardie ander $1 \%$ ? Waar pas ons in binne die evolusie van spesies? Waar pas die episode van hominiede spesies oor 2-3 miljoen jaar en van homo sapiens oor ongeveer 200000 jaar in binne die groter prentjie? Hoe help dit ons om die betekenis van kultuur (50 000 jaar) en godsopvattings (ook omtrent 50000 jaar), landbou (12 000 jaar), skryfkuns (5000 jaar), industrialisering (200 jaar) en inligtingtegnologie (30 jaar) na waarde te skat? Wat van menslike uniekheid (kyk Conradie 2007; Van Huyssteen 2006)? Is alles anders aan ons onderwerp? Is ons regtig die 'kroon van die skepping'? Wat gemaak met die sogenaamde 'siel' van die mens? Hoe moet ons in die reine kom met ons eie sterflikheid?

Hierdie vrae is natuurlik nie nuut nie, maar hulle word met 'n nuwe dringendheid aan die orde gestel. Hoekom? Ek twyfel of dit met aktiwiteite rondom dierebeskerming te make het. Dit spruit eerder uit die bewuswording van die ekologiese impak van verstedeliking en industralisering. Niemand wil die voordele daarvan ontken nie, maar die skadukante daarvan is onmiskenbaar. As jou oë eers daarvoor oopgegaan het, sien jy dit orals raak. Dit is 'n kort treetjie van hierdie bewuswording na die insig dat geïndustraliseerde beskawings gebou is op die veronderstelling dat die mens 'n uitsonderingsposisie tussen alle ander spesies geniet.

Hierdie vrae is ook meer radikaal as wat dit op die oog af mag lyk. Opvattings van moraliteit, opvoeding en demokrasie, regstelsels en ekonomiese stelsels, word gebou op hierdie veronderstelling. In filosofiese nadenke ten minste sedert Immanuel Kant is die onderskeid tussen intrinsieke en instrumentele waarde gewoon as vanselfprekend aanvaar. Om dit te laat vaar, kan katastrofies wees. Immers, daar word wyd aanvaar dat jy jou eie skape mag slag, maar nie jou eie kinders nie. Jy mag 'n boom op jou grond afkap, maar nie jou buurman se boom of sy groottoon nie. In sekere kringe word dit egter bevraagteken met oproepe soos 'Meat is murder!' of Thomas Berry se voorstel van 'n 'parliament of all creatures'. Berry (1988:209) het bygevoeg dat die eerste besluit van so 'n parlement (waar elke spesie een verteenwoordiger het) bes moontlik sal wees om ontslae te raak van die mens as spesie omdat ons heeltemal te gevaarlik vir alle ander spesies se voortbestaan is. Die bevraagtekening van die mens se uitsonderingsposisie is inderdaad radikaal, dit dring deur tot die wortels van ons bestaan. Enige vanselfsprekende antwoorde op hierdie vrae is nie meer moontlik nie, maar ons het ten minste voorlopige antwoorde daarop nodig elke oggend wanneer ons opstaan, al weet ons alte goed dat daardie antwoorde bra ontoereikend is.

\section{Waarom draai die geskiedenis?}

'n Tweede stel vrae handel oor die betekenis van die geskiedenis. Waarheen is ons op pad? Geen mens kan 'n antwoord daarop ontbeer nie. 'n Student wat dit nie weet nie, sal sukkel om te konsentreer op die leeswerk vir môre se toets of eksamen. 'n Politieke party wat geen visie vir kiesers kan voorhou nie sal gou ondergaan. Die vraag kan met 'n kleiner of 'n groter skopus gevra word - oor die sin en rigting van my lewe, van my familie, my gemeenskap, my taal, my land, my kontinent, my spesie, my planeet. In godsdienstige vorm: Wat is God besig om te doen in my lewe, in my gesin, in hierdie gemeente, hierdie wêreld waarin ons woon? Dit is ' $n$ vraag wat gelowiges nie onbeantwoord kan laat nie, maar enige iemand wat meen om die vinger van God in die geskiedenis te kan raaksien, beweeg noodwendig op gevaarlike terrein (kyk Durand 1987).

Hierdie vrae word eweneens met 'n nuwe dringendheid opgeroep deur betrokkenheid by omgewingsorg. Die vraag is immers dit: Help wat ek nou doen om die groter ekologiese probleme die hoof te bied? Die antwoord is altyd bevestigend, maar die kulturele onsekerheid wat aanleiding gee tot die vraagstelling moenie onderskat word nie. Dit blyk die duidelikste uit apokaliptiese toekomsbeelde in die media. Wetenskapsfiksie hou selde aan ons 'n idiliese bestaan voor. Die beelde is eerder katastrofies en geweldadig, al is daar darem gewoonlik die een of ander messias wat 'n klein groepie uitverkorenes red van die magte van die duisternis (kyk Santmire 1989). Diegene van ons wat weinig ooghare daarvoor het, kan nietemin nie help om te wonder 
waarheen hierdie beskawing op pad is nie. Hoe hou hierdie toekomsbeelde verband met tegnologiese optimisme, mediese beloftes vir 'n nog langer lewe en uitsprake oor ekonomiese groei wat die einde van armoede kan bring? Hoe sal die wêreld lyk oor 50 of 100 jaar van nou af? Hoe speel my lewenstyd daarbinne af?

Hierdie soort vrae het 'n eksistensiële diepgang vir enige mens in die sogenaamde verbruikersklas (kyk Conradie 2009) wat tussen 1950 en 2050 lewe. Dit gaan hier oor die betekenis van 'n era en die veronderstellings waarop dit gebou is. Meer spesifiek gaan dit oor die energiebasis van die huidige wêreldekonomie. Hierdie 100 jaar sal in die geskiedenis bekend staan as die een wat meer as die helfte van die planeet se beskikbare voorrade van olie opgebruik het. Dit het verreikende implikasies wat aangedui word deur bykans apokaliptiese merkers soos 'peak oil' en 'antropogeniese klimaatsverandering'. Nog meer: kan 'n paar generasies die beskikbare voorrade van uraan min of meer opgebruik en die volgende 200 generasies laat om die kernafval te versorg? Dit is soortgelyk aan vrae wat iemand wat langdurig betrokke was by die sogenaamde grensoorlog in die 1970's en die 1980's of by die opbou van die Nasionale Party noodwendig nou moet vra: Watter betekenis het daardie werk vandag nog? Watter tyd is dit waarbinne ons leef en hoe pas my lewe daarbinne in? Uiteindelik bring dit ons by die vraag waarheen die geskiedenis van die Westerse beskawing, van geïndustraliseerde kapitalisme, van my middelklasbestaan op pad is. Indien die ergste scenarios rondom klimaatsverandering bewaarheid sou word (kyk byvoorbeeld Lovelock 2009), dan sal die $10 \%$ van die huidige wêreldbevolking wat oor 100 of 200 jaar miskien nog daar sal wees onmiskenbaar vra na die betekenis van die 100 jaar tussen 1950 en 2050. Ons kan nie anders as om nou al voorlopige antwoorde daarop te vind nie. Of mense dit dán toereikend sal vind, is ' $n$ ander vraag!

\section{Waarvoor deug kennis?}

'n Derde stel vrae handel oor kennis. Dit gaan nie soseer oor wat kennis is nie, maar veral oor waarvoor kennis ingespan word, hoe betroubare kennis bekom kan word en watter plek kennis in die samelewing behoort te speel. Elkeen hiervan word opgeroep en geradikaliseer deur 'n ontluikende ekologiese bewuswording. Die logika is eenvoudig: histories gesproke is die industriële omwenteling die direkte aanleidende oorsaak van die sogenaamde ekologiese krisis. Daaragter lê tegnologiese vooruitgang en daaragter lê weer die opkoms van die moderne wetenskap. Dit is moontlik gemaak deur ontwikkelinge in Europa rondom die Renaissance, die Protestantse Reformasie, die godsdiensoorloë wat daaruit gespruit het en die verligting as ' $n$ antwoord daarop: Die samelewing kon nie langer op godsdienstige affiliasie gebou word nie; rasionele besluitneming moet eerder die deurslag gee. In die literatuur word kortweg van 'moderniteit' gepraat as die denkklimaat waarbinne wydverspreide ekologiese vernietiging moontlik geword het. Twee aspekte van die moderne denkklimaat is hier van belang, naamlik die drang op beheersing van die magte van die natuur (wat is kennis) en die subjek-objek-tweedeling wat daarmee saamhang (hoe word kennis opgedoen).

Die tegnologiese toepassings van die beheersing van die natuur roep vandag opnuut vrae op oor die rol van kennis. Dit is immers nie ' $n$ doel opsigself nie. In klassieke nadenke hieroor word twee moontlikhede genoem, naamlik kennis as deug en kennis as mag. Kennis kan as 'n deug beoefen word deur klem te plaas op 'n bereidheid om te leer en te lees, deur weetgierigheid, nuuskierigheid, uitvinding, analitiese en sintetiese vaardighede, kritiese nadenke, ensomeer. Dit is basiese akademiese deugde wat deel vorm van wat universiteite die 'attribute' van graduandi noem. Eenvoudiger gestel is kennis as deug belangrik ter wille van insig en veral wysheid, die eerste van die sogenaamde kardinale deugde. Hierteenoor staan kennis as mag in die sin van tegnologiese mag, maar natuurlik ook ekonomiese mag en politieke mag (sien ook die rol van militêre inligting). Die sogenaamde inligtingrevolusie is gebaseer op hierdie opvatting van kennis as mag in 'n kennisgebaseerde samelewing. Kennis as mag is noodsaaklik maar natuurlik ook gevaarlik. Dit lei tot mediese deurbrake maar ook tot meer gesofistikeerde wapens. 'n Derde opvatting van kennis het in die verbruikerskultuur posgevat, naamlik kennis as vermaak en plesier. Hier word dit belangrik vir die kenner om kennis op só 'n manier aan te bied dat dit aantreklik vir moontlike kopers sal wees. Hulle betaal vir die aanbieding omdat hulle daardeur vermaak wil word. Veral eerstejaar studente kom met hierdie soort opvatting van kennis na vore. Dosente word dan vermaaklikheidskunstenaars wat groot klasse van betalende kliënte moet boei met hulle kennis en wat moet kompeteer met ander attraksies (kyk Conradie 2011b). Eksamens is hiervolgens ' $n$ hinderlike struikelblok ten einde 'n graad, 'n goeie werk met ' $n$ goeie salaris en daarmee 'n goeie lewe te verseker.

Die rol van universiteite binne die samelewing moet eweneens herdink word aan die hand van hierdie vrae. Dit word selfs in universiteite se leuses vervat. Stellenbosch is vir jou ' $\mathrm{n}$ kennisvennoot, terwyl Universiteit van WesKaapland (UWK) 'n 'kwaliteit plek is waar jy kan groei'. Brian $\mathrm{O}^{\prime} \mathrm{C}$ onnel, die huidige rektor van UWK, praat gereeld van die hermeneutiese rol van universiteite in terme van 'sense-making'. Elke fakulteit moet die samelewing help om sin te maak van die wêreld waarbinne ons lewe.

In ekologiese nadenke word die tweedeling tussen 'n kennende subjek en 'n gekende objek meermale as die kern van die onderliggende probleem raakgesien. Veral in die konteks van wat as 'deep ecology' bekend staan, word gesoek na 'n nuwe verstaan van die subjek. Dit gaan nie hier net daaroor dat ' $n$ mens se selfbegrip deur verhoudings met ander mense gedefinieer word nie (ubuntu). Daardie 'ander' sluit ook ander organismes en fisisese verskynsels in. Ons lewe nie 'op' die aarde nie, maar vorm deel van die biosfeer. Ek deel my liggaam nie net met ander nie, maar ook met miljoene bakterieë wat binne my 'n eie bestaan voer. Ek vorm deel van die vloei van water, lug en voedsel binne die ekosisteem waarbinne ek voorkom. Volgens James Lovelock 
se bekende Gaia-hipotese vorm alle lewe op aarde trouens deel van een groter en volgens hom sterwende organisme. Hier word die begrip 'netwerk' gebruik om aan te dui dat die onderskeid tussen individu en omgewing kunsmatig is. Dit is beter om 'individuele' as 'n byvoeglike naamwoord te gebruik eerder as 'n 'individu' as naamword. Ek sorg nie soseer vir die oerwoud nie; ek vorm deel van die woud wat vir myself sorg. Hier is sprake van 'n verstaan van die Self waarin 'n organisme deel vorm van 'n groter geheel. Die afstand tussen subjek en objek word oorbrug sodat dit wat meer subjektief is meer betroubaar is. Objektiverende kennis is daarenteen gevaarlik en onbetroubaar. Hiermee word die rol van emosie, stories, digkuns, mites en rituele in die verwerwing van kennis merkwaardig genoeg weer sentraal. Die breuk met moderniteit is radikaal (kyk Desjardin 2012:207-220).

\section{Waarom gaan dit in werklikheid?}

Die groeiende insig in die skadukante van moderniteit het opnuut ' $n$ belangstelling gewek in die rol van wêreldbeelde. Die modernistiese ovatting van kennis is ingebed in 'n bepaalde verstaan van die werklikheid wat gevoed is deur die empiriese sterrekunde van Galileo en deur die fisika van Newton. Hier is sprake van 'n meganistiese wêreldbeeld: die wêreld funksioneer volgens die meganika van 'n masjien waarvan God die intelligente ontwerper is. Hierdie wêreldbeeld word wyd gekritiseer, maar hoe moet ons dan anders na die wêreld leer kyk? Dit is verstommend om te sien in watter mate ekologie met kosmologie verbind word in talle verskillende kontekste. Selfs diegene wat hulle met die klein detail van mikroörganismses besig hou, vra al gou na die groter prentjie waarbinne dit inpas. Dit lei weliswaar tot heelwat verwarring in die gebruik van die begrip 'wêreldbeeld'. Dit word gebruik in heel uiteenlopende kontekste soos astrofisika (waar die term kosmologie weliswaar verkies word), neo-Calvinisme, kennissosiologie, nadenke oor inheemse kulture en godsdienste (byvoorbeeld 'n tradisionele Afrika wêreldbeeld), in rekonstrukises van die 'geskiedenis van die heelal' by denkers soos Teilhard de Chardin, Thomas Berry en Brian Swimme en selfs binne 'n liturgiese konteks (kyk Lathrop 2003). Voorwaar 'n vreemde mengelmoes!

Ek wil twee aspekte hiervan uitlig. Eerstens is dit belangrik om ons daaraan te herinner dat ons nie'n geheelbeeld van die wêreld kan vorm nie. Ten spyte van woorde soos 'worldview' kan ons nie die wêreld sien nie omdat ons daarbinne gesitueer is. Dit is onmoontlik om die geheel raak te sien. 'n Sogenaamde holistiese benadering is daarom pretensieus. Ons kan alleen konstruksies van die geheel maak en ons doen dit op grond van 'n uitermate klein fragment daarvan gebaseer op ons eie ervaring en afgeleide kennis. Wanneer ek die woord 'UWK' gebruik, doen ek dit op grond van 'n klein breukdeel van die geskiedenis van die universiteit oor meer as 50 jaar. Ek kan nie die geheel sien nie, want dan sou ek elke student, dosent en personeellid moes ken wat al aan die universiteit verbonde was. Ek sou elke klas, vergadering en byeenkoms moes bywoon; in elke kantoor en klaskamer inloer, elke epos lees, weet wat in elke rekenaar geliaseer is. Ek sou boonop alle antwoordstelle, werkopdragte en navorsingsuitsette moes lees. Ek dink selfs nie God sou dit graag wou doen nie! Dieselfde geld van woorde soos 'Kaapstad', 'Suid-Afrika' of 'mens'. Nietemin gebruik ons sulke woorde sonder enige huiwering en kan met ander daaroor kommunikeer. Trouens, dit lyk asof die vermoë tot blitssnel simboliese kommunikasie een van die mens se evolusionêre voordele is.

Tweedens is ons konstruksies van die geheel natuurlik nie onskuldig nie. Dit maak saak met watter wêreldbeeld ons werk. Hier is verskillende vlakke van belang. Wetenskaplike insigte bied die grondvlak. Dit maak 'n verskil of jou wêreld drie verdiepings het (soos soms in bybelse tye veronderstel is), of die aarde rond is en in die lug hang (soos Calvyn reeds geweet het, maar dit nie kon verklaar nie) en of jy die insigte van Copernicus, Galileo, Newton, Darwin en Einstein verwerk het. Wetenskaplike insigte is egter nie naastenby genoegsaam nie. Die vraag bly immers waar die wêreld uiteindelik vandaan kom. Hier is daar nie baie opsies nie: jy het ' $n$ keuse tussen wetmatige noodsaaklikheid (die Noodlot), ewekansigheid (Geluk), 'n spel daartussen of die een of ander vorm van planmatigheid (God?).

Ons beelde van die werklikheid funksioneer ook op 'n ander vlak. Ons kan die natuur byvoorbeeld beskryf as 'uitsonderlik mooi en romanties' om in te verwyl (as jy die tyd en geld daarvoor het), as 'niks anders as bloed en stryd' en daarom as iets om te vrees, as 'braakland om in te palm en te ontgin', as 'bemarkbare eiendom' of as iets subliem wat aanbid moet word (kyk Snyder 2011:42-45). Dit bring mens by 'n ander vraag, naamlik waaromheen die wêreld (die samelewing) nou eintlik draai. Gaan alles uiteindelik oor geld, mag, roem, plesier, kennis, liefde, burgerskap, vriendskap of dalk oor God se eer? Hoe ons die wêreld sien, het belangrike implikasies vir ons oriëntasie binne daardie wêreld, hoe ons ons lewe daarvolgens inrig (kyk Lathrop 2003:51-67) en wat ons hande vind om te doen.

Op 'n meer teologiese vlak, kan 'n mens sê dat Christene die wêreld verstaan as God se skepping en dit daarom aan God toeskryf. Maar ook hier kom daar verskillende beelde na vore (kyk ook Migliore 2004:111-113). Is God as Skepper soos 'n fontein van waaruit alles voortvloei? Of is die wêreld God se pottewerk? Of dalk 'n goed geoliede masjien? Of die nodige hardeware wat die beplande sagteware moet kan hanteer? Is die wêreld eerder God as 'Ekonoom' (kyk Meeks 1989) se huishouding? Is dit dalk selfs God se liggaam (byvoorbeeld McFague 1993)? Of God se kind (Fensham 2012)? Of God se kunswerk? In elke geval is hier heelwat op die spel. Hoe ons beeld van die wêreld gevorm word, sal die wyse waarop ons daarmee omgaan verreikend beïnvloed.

\section{Gevolgtrekking}

Ek het hierbo probeer aandui dat betrokkenheid by omgewingsorg ' $n$ mens heel gou uitbring by klassieke vrae rondom menswees, kultuur en geskiedenis, kennis en 
die werklikheid opsigself. Elkeen van hierdie vrae word gestimuleer deur jou hande vuil te maak. Dit gaan nie vir my hier soseer oor watter vrae opgeroep word nie, maar eerder om daarop te wys hoedat hierdie vrae opgeroep word deur ekologiese besorgdheid. Die merkwaardige is hoe vinnig dit gebeur dat 'n mens in 'n netwerk van vrae verwikkel raak, hoe spoedig 'n mens kan kom van ekologie tot by kosmologie en tot by spiritualiteit. In elke geval is daar 'n bepaalde logika aanwesig waarin dit wat voor die hand liggend is, geplaas word binne ' $n$ groter raamwerk wat noodwendig onoorsigtelik is. Daardie raamwerk - rondom menswees, geskiedenis, kennis en die werklikheid op sigself - is egter nie net onoorsigtelik nie, maar word ook (radikaal) skeefgetrek. Dit altans is die intuïsie en suspisie van diegene wat hulle hande vuil maak rondom omgewingsorg.

Dit is nodig om nog weer daarop te wys dat ons as mense eintlik nie anders kan as om hierdie soort vrae te stel nie. Dit word opgeroep orals waar ons ons hande vuilmaak. Ons weet egter maar alte goed dat ons op geen manier finale antwoorde daarop kan vind nie. Ons bly staan (en gaan!) met leë hande. Terselfdertyd het ons egter ook voorlopige antwoorde nodig. Die antwoorde moet daarom toereikend genoeg wees om te kan aangaan met jou lewe. Jy moet jou vertroue daarop kan plaas. Dit dui iets van die patos van menswees aan: Ons kan nie anders as om vrae te stel wat ons nie kan beantwoord nie. En ons kan ook nie anders as om wel antwoorde te gee nie en daardie antwoorde maak saak. Baie! Dis maklik om ander se vrot antwoorde raak te sien, maar juis omdat ons ons vertroue moet plaas in ons eie antwoorde is dit moeiliker om hulle gebreke vas te gryp. Die ontluikende ekologiese krisis het ' $n$ wydverspreide gewaarwording gebring dat die antwoorde waarop 'n geïndustraliseerde ekonomie gebou is ons in die moeilikheid laat beland het.

Juis omdat ons ons vertoue moet plaas op die voorlopige antwoorde wat ons gevind het, kan ons myns insiens ook nie anders as om te soek na iets wat meer toereikend en minder voorlopig is nie. Hierdie is die soeke na spiritualiteit, na dit wat méér is, na iets wat groter is as onsself en ons nietige bestaan, iets waarbinne ons onsself kan verloor en waarvoor ons onsself kan gee. Dit bring ons opnuut by die vraag na God. Dit is die weg wat lei tot ekologiese teo-logie. Die vraag na God is nie alleen 'n spekulatiewe vraag nie, maar ook 'n eksistensiële vraag. As jou hande vuil is, in die dubbele betekenis van die woord, dan soek jy na God. As jy wel skuldig is, as jou hande vol bloed is, moet jy dit egter eers raaksien. Daarvoor moet jy in die spieël van die kennis van God kyk, aldus Calvyn (kyk Van der Kooi 2002).

Ek wil byvoeg dat Christene nie sonder meer daarop kan aanspraak maak dat hulle vooraf geopenbaarde antwoorde op hierdie soort vrae het nie. Hulle is daarvoor te tergend en te ontwykend. Dit plaas Christene naas alle ander mense en ander godsdienste in die soeke na die diepste geheimenis van die wêreld. Dit plaas teologiese nadenke naas enige ander dissiplines, die wetenskappe, filosofie en kuns in die soeke daarna om sin te maak van die wêreld rondom ons. Die gevaarlike vraag na die oneindige word net soseer gestel deur Richard Dawkins as deur Albert Einstein, deur Adolf
Hitler as deur Julius Malema, deur Bill Gates as Lasarus die bedelaar.

Christene bely wel dat hulle een bepaalde leidraad gevind het - op die mees onwaarskynlikste plek denkbaar - wat hulle nogal kan help met hulle vuil hande. Trouens hulle vertel dit eerder só: dat die leidraad hulle gevind het. Die vraag is nou net of hierdie leidraad hulle kan help om die moord op te los en of hulle regtig dink dat hulle met moord kan wegkom. Ekologiese teologie bied daarom nie alleen 'n Christelike kritiek op ekologiese vernietiging nie; dit bied ook 'n ekologiese kritiek op die Christelike tradisie, in die hoop om dit van binne uit te vernuwe, in die hoop op 'n nuwe, 'n ekologiese hervorming van die Christelike geloof.

\section{Erkenning Mededingende belange}

Die outeur verklaar dat hy geen finansiële of persoonlike verbintenisse het met enige partye wat hom nadelig of voordelig kon beïnvloed het in die skryf van hierdie artikel nie.

\section{Literatuurverwysings}

Berry, T., 1988, The dream of the earth, Sierra Club Books, San Francisco.

Buchan, A., 2006, Faith like potatoes: The story of a farmer who risked everything for God, Monarch Books, London.

Conradie, E.M., 2005, An ecological Christian anthropology: At home on earth?, Ashgate, Aldershot.

Conradie, E.M., 2006, Waar op dees aarde vind mens God? Op soek na 'n aardse spiritualiteit, Lux Verbi.BM, Wellington.

Conradie, E.M., 2007, 'Human distinctiveness as a journey of discovery of (human) finitude', Journal of Theology for Southern Africa 128, 4-17.

Conradie, E.M., 2009, Uitverkoop? In gesprek oor die verbruikerskultuur, Lux Verbi. $\mathrm{BM}$, Wellington.

Conradie, E.M., 2011a, 'Christianity and Earthkeeping: In search of an inspiring vision', Resources in Religion and Theology 16, n.p.

Conradie, E.M., 2011b, 'Knowledge for sale? The impact of a consumerist hermeneutics on learning habits and teaching practices', Koers 76(3), 423-447. http://dx.doi.org/10.4102/koers.v76i3.36

Conradie, E.M. (ed.), 2012, 'Pneumatology and ecology', Journal of Reformed Theology 6(3), 189-305. http://dx.doi.org/10.1163/15697312-12341269

Desjardin, J.R., 2012, Environmental ethics: An introduction to environmental philosophy, 5th edn., Thompson Wadsworth, Toronto.

Durand, J.J.F., 1987, 'Die vinger van God in die geskiedenis - 'n Onopgeloste probleem', in J.J.F. Durand (red.), Teks binne konteks, bl. 91-99, Universiteit van Wes-Kaapland, Bellville.

Edwards, D., 2004, Breath of life: A theology of the Creator Spirit, Maryknoll, Orbis Books. Everett, W.J., 2008, Red Clay, Blood River, Booklocker.com Inc, n.p. (Electronic version). Fensham, C., 2012, 'The sacrament of the first child of God: A renewed Christian ecoimaginary', Scriptura 111, 323-332.

Fox, M., 1991, Creation spirituality: Liberating gifts for the peoples of the earth, Harper \& Row, San Francisco.

Lathrop, G.W., 2003, Holy ground: A liturgical cosmology, Fortress Press, Minneapolis. Leopold, A., 1949, A Sand County almanac, Ballantine, New York. PMCid:PMC437398 Lovelock, J., 2009, The vanishing face of Gaia: A final warning, Basic Books, New York. Meeks, D., 1989, God the economist: The doctrine of God and political economy, Fortress Press, Minneapolis.

Migliore, D.L., 2004, Faith seeking understanding: An introduction to Christian theology, 2nd edn., W.B. Eerdmans, Grand Rapids.

McFague, S., 1993, The body of God: An ecological theology, SCM Press, London.

Pirsig, R., 1974, Zen and the art of motorcycle maintenance, Corgi Books, London.

Santmire, H.P., 1989, 'The future of the cosmos and the renewal of the church's life with nature', in T.F. Peters (ed.), Cosmos as Creation, pp. 265-282, Nashville, Abingdon.

Snyder, H.A., 2011, Salvation means creation healed: The ecology of sin and grace, Cascade Books, Eugene, OR.

Van der Kooi, J.C., 2002, Als in een spiegel: God kennen volgens Calvijn en Barth, J.H. Kok, Kampen.

Van Huyssteen, J.W., 2006, Alone in the world?, W.B. Eerdmans, Grand Rapids. PMid:16645122

Versfeld, M., 1968, Klip en Klei, Human \& Rousseau, Kaapstad. 